Doctors, Patients and Society: Power and Authority in Medical Care

\author{
Eds Martin S Staum and \\ Donald E Larsen, \\ Ontario, Wilfrid Laurier University \\ Press, 1982 \\ $\$ 9.50$
}

There was a time, in the not so distant past, when many members of the medical profession appeared to believe that the ethics they absorbed by an immaculate process of osmosis when the mantle of qualification fell upon them were patently unquestionable by right-minded people. Moral certitude reigned supreme. Unethical conduct unfortunately occurred from time to time: it was easily recognised as personal moral turpitude affecting vicariously the reputation or livelihood of other members of the profession. Members guilty of it required the supreme punishment, professional banishment. Moral dilemmas surrounding the objectives or sequelae of medical intervention were fictional or dramatic concoctions, not part of the real everyday, morally uncontaminated business of medicine.

The recent growth of moral sensibility concerning the tasks and role of medicine is a phenomenon which itself could do with socio-historical analysis, and it will undoubtedly get it in the coming years. In the meantime, bookshelves in academic institutions throughout the Western world are filling up with the recorded proceedings of conferences and seminars in which the moral, social, political and economic implications of Western medicine as it is now practised (or as it is likely to be practised in the foreseeable future) are examined and re-examined from a variety of disciplinary perspectives. The medical profession is no longer able, even if it wished, which many of its members clearly do not, to claim that its dilemmas are its concern alone.

The present volume, coming from the Calgary Institute for the Humanities in Alberta, Canada is an example of the genre and a rather good example. It reports what was clearly a well organised workshop and firm editorial control has been exercised. The participants who provided the papers included six medical doctors, one of them the Dean of a medical school, another, Thomas McKeown whose work on the role of medicine is well known in
Britain. There were three bioethicists who I take to be philosophers who have developed a particular interest in ethical principles and their application to the interferences with human bodily and mental functioning which are most likely to be carried out today by doctors. There were also three social historians and one representative of each of the following disciplines: anthropology, economics, law, nursing and sociology.

Nearly all the contributions are lucidly presented. Controversial interpretations and prescriptions are challenged. The editors locate the issues of the power and authority which are vested in the medical care professions today in the social, economic, technological and cultural context of the last two decades. Anyone reading at random should find some nugget to add to his or her store of wisdom. The book as a whole contains many illustrations of the valuable light which other approaches to medicine can throw on the practitioner's inescapable role in the functioning of society. This reviewer, a sociologist, found the historical contributions and those of the lawyer and bioethicists particularly interesting. The book is published in paperback and at the price offered should be within the reach of impoverished academics and their institutions as well as that of postgraduate medical centres.

PROFESSOR MARGOT JEFFERYS

Emeritus Professor of Medical Sociology, Bedford College, London.

\section{The Artificial Family}

R Snowden and G D Mitchell

London, George Allen and Unwin Ltd, 1981

$£ 12.50$

Robert Snowden is a Senior Lecturer in Sociology at the University of Exeter and also Project Director of the Institute of Population Studies at the University of Exeter. Duncan Mitchell is the Director of the same institute and Professor of Sociology at Exeter. They have written The Artificial Family not to offer solutions but to examine the relationship of the Artificial Insemination by Donor (AID) family to society. They are close colleagues of Dr Margaret Jackson who has been one of the pioneers of donor insemination over the last 50 years in this country. Through Margaret Jackson, who has spent her working life in Exeter, they have been able to contact couples who were referred to her for consideration for AID.
Snowden, Mitchell and their team of researchers have managed to interview in depth some of these couples.

The Artificial Family is a stimulating book which reviews the history of AID, beginning with the first recorded case performed in America in 1884, and then discusses the AID couple's desire for a child, the role of the donor, and lastly, the AID child and its family.

They highlight the secrecy which they feel still surrounds AID and discuss whether this should be allowed to continue. They discuss the current legal situation and conclude by asking 59 questions which they feel need answering concerning the AID child, the recipients of AID, the family, the donor, the donor's family, the AID practitioner and contemporary society.

As a medical practitioner working in the field of infertility I am sure this book has an invaluable contribution to make and will stimulate the workers in this field to think about the wider implications of AID. However, I found some of the comments negative rather than constructive.

AID has now been practised for nearly 100 years, has been accepted by society and brings happiness to many childless couples. Adoption is not at present a realistic alternative for childless couples as the demand for infants available for adoption far outstrips the supply.

DR BRIDGETT A MASON 25 Weymouth Street London

\section{Medical Law for the Attending Physician, a Case-oriented Analysis}

Salvatore Francis Fiscina

Southern Illinois University Press, 1982 $\$ 40.00$

This is an American book and the advance notice of its publication begins with the question: "Will the doctor be sued?' and this could very well be the title. Dr Fiscina sees every doctor as a suit for medical negligence waiting to happen. In his preface he states:

'The impact and effect of law on medical practice have created suspicion and confusion among physicians concerned with their professional legal obligations. This book is intended to guide the practitioner through a journey which highlights medicolegal landmarks by illustrating professional conduct in the clinical context.' 